\title{
Antiproliferative activity of essential oils from three plants of the Brazilian Cerrado: Campomanesia adamantium (Myrtaceae), Protium ovatum (Burseraceae) and Cardiopetalum calophyllum (Annonaceae)
}

\author{
C. C. F. Alves ${ }^{a}$ (D), J. D. Oliveira ${ }^{a}$ (D), E. B. B. Estevam ${ }^{a}$ (D) M. N. Xavier ${ }^{a}$ (D), \\ H. D. Nicolella ${ }^{\text {(DD , R. A. Furtado }}$ (D), D. C. Tavares ${ }^{b}$ (D) and M. L. D. Miranda ${ }^{*}$ \\ anstituto Federal de Educação, Ciência e Tecnologia Goiano, Campus Rio Verde, Av. Sul Goiana, s/n, Zona Rural, \\ CEP 75901-970, Rio Verde, GO, Brasil \\ ${ }^{\mathrm{b}}$ Centro de Pesquisa em Ciências Exatas e Tecnologia, Universidade de Franca, Av. Dr. Armando de Salles Oliveira, 201, \\ Parque Universitário, CEP 14404-600, Franca, SP, Brasil \\ 'Instituto Federal de Educação, Ciência e Tecnologia do Triângulo Mineiro - Campus Uberlândia Centro, \\ Rua Blanche Galassi, Morada da Colina, CEP 38411-104, Uberlândia, MG, Brasil \\ *e-mail: maykermiranda@iftm.edu.br
}

Received: March 8, 2018 -Accepted: June 14, 2018 - Distributed: February 28, 2020

\begin{abstract}
Essential oils, which may be extracted from several parts of plants, have different biological activities. The Brazilian Cerrado has a large variety of plants that yield essential oils, even though many have not been studied yet. Taking into account the biodiversity of this biome, this study aimed at evaluating the antiproliferative activity of essential oils extracted from three species of plants of the Cerrado in Goiás state: Campomanesia adamantium (Cambess.) O. Berg, Protium ovatum (Engl. in Mart.) and Cardiopetalum calophyllum (Schltdl.). Essential oils were extracted from both C. adamantium and C. calophyllum leaves and from $P$. ovatum leaves and green fruits by hydrodistillation carried out by a Clevenger-type apparatus. The chemical composition of the essential oils was determined by Gas Chromatography coupled to Mass Spectrometry (GC-MS). The following major chemical constituents were identified in the essential oils under investigation: $\beta$-myrcene (62.00\%), spathulenol $(28.78 \%)$, germacrene-B $(18.27 \%)$, $\beta$-caryophyllene oxide $(16.40 \%), \beta$-caryophyllene $(14.00 \%), \alpha$-pinene $(11.30 \%)$, viridiflorol $(9.99 \%)$, limonene $(7.30 \%)$ and $(Z, E)$-pharnesol (6.51\%). The antiproliferative activity was evaluated in different human tumor cell lines: breast adenocarcinoma (MCF-7), cervical adenocarcinoma (HeLa) and glioblastoma (M059J). A normal human cell line was included (GM07492A, lung fibroblasts). Results showed that essential oils from $C$. adamantium leaves got the lowest values of $\mathrm{IC}_{50}$ in all strains of tumor cells under evaluation. They were significantly lower than the ones of the normal cell line, an evidence of selectivity. It is worth mentioning that this is the first report of the antiproliferative activity of essential oils from C. adamantium, P. ovatum and C. calophyllum against human tumor cells.
\end{abstract}

Keywords: essential oils, Cerrado, antiproliferative activity, tumor cells.

\section{Atividade antiproliferativa dos óleos essenciais de três plantas do Cerrado brasileiro: Campomanesia adamantium (Myrtaceae), Protium ovatum (Burseraceae) e Cardiopetalum calophyllum (Annonaceae)}

\section{Resumo}

Os óleos essenciais podem ser extraídos de várias partes das plantas e apresentam diversas atividades biológicas. O Cerrado brasileiro possui uma grande variedade de plantas produtoras de óleos essenciais muitas delas ainda não estudadas. Levando-se em consideração a biodiversidade desse bioma, o objetivo deste trabalho foi avaliar a atividade antiproliferativa dos óleos essenciais extraídos de três espécies de plantas ocorrentes no Cerrado do estado de Goiás: Campomanesia adamantium (Cambess.) O. Berg, Protium ovatum (Engl. in Mart.) e Cardiopetalum calophyllum (Schltd1.). Os óleos essenciais foram obtidos das folhas de C. adamantium e C. calophyllum e das folhas e frutos verdes de $P$. ovatum por hidrodestilação, usando o aparelho do tipo Clevenger. A composição química dos óleos essenciais foi determinada pelo método de Cromatografia Gasosa acoplada à Espectrometria de Massas (CG-EM). Os constituintes químicos majoritários identificados nos óleos essenciais estudados foram: $\beta$-mirceno (62,00\%), espatulenol (28,78\%), germacreno-B (18,27\%), óxido de $\beta$-cariofileno (16,40\%), $\beta$-cariofileno (14,00\%), $\alpha$-pineno $(11,30 \%)$, viridiflorol $(9,99 \%)$, limoneno $(7,30 \%)$ e $(Z, E)$-farnesol $(6,51 \%)$. A atividade antiproliferativa foi avaliada em diferentes linhagens 
de células tumorais humanas: adenocarcinoma de mama (MCF-7), adenocarcinoma cervical (HeLa) e gliobastoma (M059J), além de, uma linhagem celular humana normal (GM07492A, fibroblastos pulmonares). O óleo essencial das folhas de C. adamantium exibiu menores valores de $\mathrm{Cl}_{50} \mathrm{em}$ todas as linhagens celulares tumorais avaliadas, sendo menores que aquele obtido na linhagem celular normal, indicando seletividade. Este é o primeiro relato da atividade antiproliferativa dos óleos essenciais de C. adamantium, P. ovatum e C. calophyllum contra células tumorais humanas.

Palavras-chave: óleos essenciais, Cerrado, atividade antiproliferativa, células tumorais.

\section{Introduction}

The Brazilian Cerrado (savanna) biome, which is a great source of medicinal plants, comprises several pharmacologically active species that have been used in folk medicine and contribute to significant knowledge of bioactive compounds and for the development of herbal remedy (Ribeiro et al., 2016). Essential oils yielded by these medicinal plants have been defined as complex mixtures of volatile, lipophilic, usually odoriferous, liquid and oily - at room temperature - substances which have broad biological application (Santos et al., 2013).

Most cancer treatments have been considered one of the most challenging problems in medicine nowadays. The search for new drugs that display activity against several types of cancer has become one of the most interesting subjects in the field of natural products. As a result, several experimental and epidemiological studies have shown that some plants may promote chemopreventive and/or antineoplastic activity (Oliveira et al., 2014). It is known that $50 \%$ of therapeutic agents used in cancer treatments have natural origin, mainly essential oils, which have drawn researchers' interest worldwide due to the fact that some have important antiproliferative activity (Al-Hajj et al., 2017).

Species of the genus Campomanesia have been widely used as infusions to treat ulcers, diarrhea and inflammation by popular medicine (Matos et al., 2015). More specifically, the species $C$. adamantium is a plant of the Myrtaceae family - also popularly known as guavira, gabiroba and guabiroba in Portuguese - whose bush is from 0.5 to $1.5 \mathrm{~m}$ high (Oliveira et al., 2016). A study of essential oils from C. adamantium reported high concentration of sesquiterpenes in the essential oil from fresh leaves (Matos et al., 2015).

The species Protium ovatum (Burseraceae) - also popularly known as almecega in Portuguese - can be found in both biomes Cerrado and the Amazon Forest. Its main characteristic is to yield resins whose anti-inflammatory, immunostimulant, repellent, antinociceptive and antineoplastic activity has already been proven (Estevam et al., 2017).

Cardiopetalum calophyllum (Annonaceae) - also popularly known as imbirinha - is a typical plant of the Cerrado and can be found in central Brazil, Triângulo Mineiro, Goiás and Mato Grosso (Xavier et al., 2016a). Several biological properties of extracts from C. calophyllum, such as larvicide activity against Aedes aegypti larvae, leishmanicidal activity against both Leishmania brasilienses and Leishmania amazonenses, besides ovicidal and nymphicidal activity against Rhodnius neglectus, have been described in the literature (Xavier et al., 2016a).
Some biological activities of essential oils from C. adamantium, C. calophyllum and P. ovatum, such as leishmanicidal, trypanocidal, antibacterial, antioxidant and antifungal activity have also been reported in the literature (Estevam et al., 2017; Oliveira et al., 2016; Xavier et al., 2016a). However, the antiproliferative activity of essential oils from these three species of the Brazilian Cerrado against tumor cells has not been investigated yet.

In this study, cytotoxicity of essential oils extracted from both $C$. adamantium and C. calophyllum leaves and $P$. ovatum leaves and green fruits was screened against different cell lines. In sum, the antiproliferative activity of the essential oils these three plants found in the Brazilian Cerrado is described for the first time in this work.

\section{Material and Methods}

\subsection{Collection and identification of plant material}

Campomanesia adamantium leaves were collected on farms which belong to the Universidade de Rio Verde (UniRV), located in the Rio Verde region, in October 2014. The plant material was deposited at the Herbarium Professor Germano Guarin Neto, in agreement with voucher HJ 6561. Cardiopetalum calophyllum leaves were collected in Rio Verde city in March 2014 and the exsiccate was deposited at the herbarium of the Universidade Estadual de Montes Claros (UNIMONTES), in agreement with voucher 3815. Protium ovatum leaves and green fruits were collected at the Universidade de Rio Verde (UniRV), located in the Cerrado region, in July 2014. The plant was deposited at the Herbarium Jataiense Professor Germano Guarim Neto at exsiccate number HJ 742.

\subsection{Essential oil extraction}

Essential oils were extracted from $P$. ovatum leaves $(100 \mathrm{~g})$ and green fruits $(100 \mathrm{~g})$ and from C. adamantium and C. calophyllum leaves (100 g), which were reduced by a knife mill. They had their essential oils extracted by hydrodistillation carried out by a Clevenger-type apparatus at $100{ }^{\circ} \mathrm{C}$ for $2 \mathrm{~h}$. Thereafter, the hydrolate was submitted to liquid-liquid partition in a separatory funnel. Three washes of the hydrolate were performed with three $10 \mathrm{~mL}$ portions of dichloromethane. Total oil yield was expressed as percentage ( $\mathrm{g} / 100 \mathrm{~g}$ fresh plant material). Essential oil samples were stored at $-4{ }^{\circ} \mathrm{C}$ until further chemical and biological tests.

\subsection{GC-MS analysis of essential oils}

Gas Chromatography coupled to Mass Spectrometry (GC-MS) was carried out by a Shimadzu QP2010 with an AOC-20i auto-injector and a DB-5MS column $(30 \mathrm{~m}$ x $0.25 \mathrm{~mm}$, 
$0.25 \mathrm{~mm}$ in thickness). The carrier gas was $\mathrm{He}$ at $57.4 \mathrm{kPa}$ (pressure) and at $1.0 \mathrm{~mL} / \mathrm{min}$ (flow rate). The split ratio was $1 / 30$, the injector temperature was $250^{\circ} \mathrm{C}$ and the injected volume was $0.1 \mu \mathrm{L}$. Temperatures, which were increased at the rate of $3{ }^{\circ} \mathrm{C} / \mathrm{min}$, ranged between 60 and $240{ }^{\circ} \mathrm{C}$. MS was recorded on the electron ionization (EI) mode, with ionization energy of $70 \mathrm{eV}$ (scan time: $2 \mathrm{scan} / \mathrm{s}$ ). Identification of volatile chemical constituents was based on their retention indices, relative to a homologous series of $n$-alkanes $\left(\mathrm{C}_{10}-\mathrm{C}_{29}\right)$ and on the comparison between mass spectra and libraries (Wiley 7 and Nist 62) and references of previously published data (Adams, 2007).

\subsection{Cell lines and culture conditions}

In this study, three different human tumor cell lines were used: breast adenocarcinoma (MCF-7), cervical adenocarcinoma (HeLa) and glioblastoma (M059J). A normal human cell line (lung fibroblasts, GM07492A) was included to evaluate whether the natural product under investigation had selective activity. Cell lines were maintained as monolayers in plastic culture medium (HAM-F10 + DMEM, 1:1, Sigma-Aldrich), supplemented with 10\% fetal bovine serum (Nutricell), antibiotics $(0.01 \mathrm{mg} / \mathrm{mL}$ streptomycin and $0.005 \mathrm{mg} / \mathrm{mL}$ penicillin; Sigma-Aldrich) and $2.38 \mathrm{mg} / \mathrm{mL}$ Hepes (Sigma-Aldrich). Cells were incubated at $36.5^{\circ} \mathrm{C}$ in a humidified $5 \% \mathrm{CO}_{2}$ atmosphere.

\subsection{Antiproliferative activity assay}

Antiproliferative activity was measured by the in vitro Toxicology Colorimetric Assay Kit (XTT; Roche Diagnostics), in agreement with the manufacturer's instructions. In the experiments, cells ( $10^{4}$ cells/well) were plated onto 96-well microplates. Each well got $100 \mu \mathrm{L}$ HAM-F10/DMEM medium with essential oil at concentrations ranging from 3.91 to $500 \mu \mathrm{g} / \mathrm{mL}$. Negative (no treatment), solvent $(0.02 \%$ DMSO, dimethylsulfoxide, Sigma-Aldrich) and positive (doxorubicin, DXR, Pharmacia Brasil Ltda.) controls were included. After incubation at $36.5^{\circ} \mathrm{C}$ for $24 \mathrm{~h}$, the culture medium was removed. Cells were washed with $100 \mu \mathrm{L}$ PBS (phosphate buffered saline) to remove the treatments and then exposed to $100 \mu \mathrm{L}$ culture medium HAM-F10 without phenol red. Afterwards, $25 \mu \mathrm{L}$ XTT was added and cells were incubated at $36.5^{\circ} \mathrm{C}$ for $17 \mathrm{~h}$. Sample absorbance was determined by a multi-plate reader (ELISA - Tecan - SW Magellan vs 5.03 STD 2P) at wavelength of $450 \mathrm{~nm}$ and reference length of $620 \mathrm{~nm}$. Antiproliferative activity was assessed with the use of $\mathrm{IC}_{50}$, the concentration that was able to inhibit $50 \%$ of the cell line growth as a response parameter, which was calculated by the GraphPad Prism program by plotting cell survival against the respective concentrations of the natural product under investigation. One-way ANOVA was used for comparing means $(P \leq 0.05)$. Experiments were performed in triplicate. The selectivity index was calculated by dividing the $\mathrm{IC}_{50}$ value of the essential oils obtained for GM07492A cells by the $\mathrm{IC}_{50}$ value obtained for the tumor cell line.

\section{Results and Discussion}

Previous studies carried out by the members of this research group reported the content and the chemical composition of essential oils extracted from $C$. adamantium and $C$. calophyllum leaves and from $P$. ovatum leaves and green fruits. Mean contents of essential oils found after hydrodistillation of C. adamantium and C. calophyllum leaves and of $P$. ovatum leaves and green fruits were $0.32 \%$, $0.06 \%, 0.30 \%$ and $0.50 \%$, respectively (Oliveira et al., 2017; Xavier et al., 2016b; Estevam et al., 2017; Estevam et al., 2018).

Major constituents identified in essential oils from C. adamantium leaves were spathulenol (19.27\%), germacrene-B (18.27\%) and $\beta$-caryophyllene oxide $(12.37 \%)$ (Oliveira et al., 2017), whereas, in the ones from $P$. ovatum leaves, they were spathulenol (17.60\%), $\beta$-caryophyllene $(14.00 \%)$ and $\beta$-myrcene $(8.40 \%)$ (Estevam et al., 2017). Major constituents of essential oils from $P$. ovatum green fruits were and $\beta$-myrcene $(62.0 \%)$, $\alpha$-pinene $(11.3 \%)$ and limonene (7.3\%) (Estevam et al., 2018), while C. calophyllum leaves displayed spathulenol (28.78\%), viridiflorol (9.99\%) and $(Z, E)$-pharnesol (6.51\%) (Xavier et al., 2016b).

Taking into account all essential oils which were investigated by this study, the treatment with essential oils from C. adamantium leaves led to the lowest $\mathrm{IC}_{50}$ values, from $77.2 \pm 8.1$ to $80.5 \pm 8.8 \mu \mathrm{g} / \mathrm{mL}$, in all tumor cell lines (Table 1). Such values were significantly lower than $\mathrm{IC}_{50}$ values found in normal cell line GM07492A, whose mean selectivity index was 4.7 (Table 1). In the case of essential oils from $C$. calophyllum leaves, $\mathrm{IC}_{50}$ values ranged from $216.8 \pm 7.9$ to $353.5 \pm 1.2 \mu \mathrm{g} / \mathrm{mL}$ and selectivity was not observed. Regarding the species P. ovatum, significant reduction in cell viability was found in cell line M059J in the treatment with essential oils from leaves, whose $\mathrm{IC}_{50}$ value was $191.3 \pm 26.0 \mu \mathrm{g} / \mathrm{mL}$, significantly lower than the one found against normal line GM07492A(276.1 \pm 14.5$)$, with selectivity index equal to 1.4 (Table 1). The oil from its fruits had $\mathrm{IC}_{50}$ values which ranged from $306.0 \pm 6.2$ to $583.5 \pm 54.6 \mu \mathrm{g} / \mathrm{mL}$, with no selective effect (Table 1).

As shown in Table 1, $\mathrm{IC}_{50}$ values of essential oils from C. adamantium leaves stood out, due to the fact that these values were lower than those found by Hussain et al. (2010) for essential oils from Rosmarinus officinalis leaves against cell lines MCF-7 $\left(\mathrm{IC}_{50}=190.1 \mu \mathrm{g} / \mathrm{mL}\right)$ and $\mathrm{LNCaP}\left(\mathrm{IC}_{50}=180.9 \mu \mathrm{g} / \mathrm{mL}\right)$. These authors described that $\mathrm{IC}_{50}<10 \mu \mathrm{g} / \mathrm{mL}$ means potentially very toxic, $\mathrm{IC}_{50}$ from 10 to $100 \mu \mathrm{g} / \mathrm{mL}$ means potentially toxic, $\mathrm{IC}_{50}$ from 100 to $1000 \mu \mathrm{g} / \mathrm{mL}$ means potentially harmful and $\mathrm{IC}_{50}>1000 \mu \mathrm{g} / \mathrm{mL}$ means potentially non-toxic.

The antiproliferative activity found by this study may be justified by the presence of major chemical constituents which were identified in essential oils from C. adamantium, P. ovatum and C. calophyllum. For instance, the compounds $\beta$-caryophyllene, $\beta$-caryophyllene oxide and germacrene-B have already been identified in essential oils from Casearia 
Table 1. $\mathrm{IC}_{50}$ and selectivity index (SI) of essential oils from C. adamantium and C. calophyllum leaves and from P. ovatum leaves and green fruits against different cell lines.

\begin{tabular}{|c|c|c|c|c|c|c|c|c|}
\hline \multirow{3}{*}{ Cell lines } & \multirow{2}{*}{\multicolumn{2}{|c|}{$\begin{array}{c}\text { C. adamantium } \\
\text { Leaves }\end{array}$}} & \multirow{2}{*}{\multicolumn{2}{|c|}{$\begin{array}{c}\text { C. calophyllum } \\
\text { Leaves } \\
\end{array}$}} & \multicolumn{4}{|c|}{ P. ovatum } \\
\hline & & & & & \multicolumn{2}{|c|}{ Leaves } & \multicolumn{2}{|c|}{ Fruits } \\
\hline & $\mathrm{IC}_{50}$ & SI & $\mathrm{IC}_{50}$ & SI & $\mathrm{IC}_{50}$ & SI & $\mathrm{IC}_{50}$ & SI \\
\hline GM07492A & $369.8 \pm 15.3$ & - & $216.8 \pm 7.9$ & - & $276.1 \pm 14.5$ & - & $306.0 \pm 6.2$ & - \\
\hline MCF-7 & $77.2 \pm 8.1^{\mathrm{a}}$ & 4.8 & $353.5 \pm 1.2$ & - & $330.8 \pm 27.9$ & - & $313.6 \pm 11.1$ & - \\
\hline HeLa & $80.5 \pm 8.8^{\mathrm{a}}$ & 4.6 & $337.2 \pm 24.6$ & - & $429.8 \pm 26.2$ & - & $542.4 \pm 19.0$ & - \\
\hline M059J & $79.9 \pm 7.8^{\mathrm{a}}$ & 4.6 & $311.4 \pm 31.2$ & - & $191.3 \pm 26.0^{\mathrm{a}}$ & 1.4 & $583.5 \pm 54.6$ & - \\
\hline
\end{tabular}

Doxorubicin (DXR) was used as positive control $\left(\mathrm{IC}_{50}\right.$ values of $0.5 \pm 0.2,62.1 \pm 2.0,5.3 \pm 1.3,16.2 \pm 2.5 \mu \mathrm{g} / \mathrm{mL}$ to $\mathrm{GM} 07492 \mathrm{~A}$, MCF-7, HeLa and M059J, respectively). GM07492A (human lung fibroblasts), MCF-7 (human breast adenocarcinoma), HeLa (human cervical adenocarcinoma) and M059J (human glioblastoma). The selectivity index is the ratio between the $\mathrm{IC}_{50}$ value of the essential oils obtained for GM07492A cells and the value found for the tumor cell line. $\mathrm{IC}_{50}$ values are $\mu \mathrm{g} / \mathrm{mL}, \mathrm{mean} \pm \mathrm{SD}, \mathrm{n}=3$. ${ }^{a}$ Significantly different from the normal cell line (GM07492A) $(P \leq 0.05)$.

lasiophyla leaves and have had their anticancerous activity described in the literature (Salvador et al., 2011). Bayala et al. (2014) described the anticancerous activity of the chemical constituents $\beta$-myrcene, $\alpha$-pinene and limonene against several types of cancer. Essential oils from Xylopia frutescens leaves displayed anticancerous activity against tumor cell lines NCI-H358M and PC-3M. Viridiflorol was identified as one of their minor constituents (Ferraz et al., 2013). The terpene $(Z, E)$ - pharnesol has already been described in the literature as a strong ally against cancer (Chagas et al., 2009). Nascimento et al. (2018) had previously observed that the $\mathrm{IC}_{50}$ value of spathulenol, a major constituent in essential oils from C. adamantium leaves, was $49.3 \mu \mathrm{g} / \mathrm{mL}$ against tumor cell line MCF-7. As a result, cytotoxicity of this essential oil may be attributed - at least, partially - to the antiproliferative activity of this sesquiterpene. In short, as mentioned before, the sesquiterpene spathulenol has stood out because its anticancerous activity has been identified in essential oils from several vegetal species, such as Croton rhamnifolioides, Boswellia carterii and Commiphora pyracanthoides (Chen et al., 2013; Vidal et al., 2016).

In sum, Li et al. (2009) highlights that the antiproliferative activity of essential oils can also be attributed to synergic effects of all terpenes that are part of the chemical composition of essential oils. There may also be other active compounds at low concentrations, responsible for the promising antiproliferative effect. Therefore, further studies to better investigate the action mechanism of essential oils from C. adamantium, P. ovatum and C. calophyllum against tumor cells are needed.

\section{Conclusion}

This study described, for the first time, the antiproliferative potential of essential oils from $C$. adamantium and C. calophyllum leaves and from $P$. ovatum leaves and green fruits. Results showed promising activity against tumor cell lines MCF-7, HeLa and M059J. Major chemical constituents of essential oils from C. adamantium, C. calophyllum and $P$. ovatum were the terpenes spathulenol, germacrene-B, $\beta$-caryophyllene oxide, $\beta$-caryophyllene, $\beta$-myrcene, $\alpha$-pinene, viridiflorol, limonene and $(Z, E)$-pharnesol. The antiproliferative activity found by this study may be justified by the presence of these major constituents, since all of them have already had their anticancerous activity well described in the literature. Therefore, results of this study not only highlight $C$. adamantium, P. ovatum and C. calophyllum as potential sources in the search for new anticancerous agents but also reinforce the importance of further studies to evaluate their phytochemical, toxicological and pharmacological aspects.

\section{Acknowledgements}

The authors would like to thank FAPEG, CNPq, IFGOIANO - Campus Rio Verde and CAPES for the financial support.

\section{References}

ADAMS, R.P., 2007. Identification of essential oil components by gas chromatography/mass spectrometry. London: Allured Pub. Corp, 804 p.

AL-HAJJ, N.Q.M., ALGABR, M.N., OMAR, K.A. and WANG, H., 2017. Anticancer, antimicrobial and antioxidant activities of the essential oils of some aromatic medicinal plants (Pulicaria inuloides-Asteraceae). Journal of Food and Nutrition Research, vol. 5, no. 7, pp. 490-495. http://dx.doi.org/10.12691/jfnr-5-7-6.

BAYALA, B., BASSOLE, I.H.N., SCIFO, R., GNOULA, C., MOREL, L., LOBACCARO, J.M.A. and SIMPORE, J., 2014. Anticancer activity of essential oils and their chemical components - a review. American Journal of Cancer Research, vol. 4, no. 6, pp. 591-607. PMid:25520854.

CHAGAS, C.E.A., VIEIRA, A., ONG, T.P. and MORENO, F.S., 2009. Farnesol inhibits cell proliferation and induces apoptosis after partial hepatectomy in rats. Acta Cirurgica Brasileira, vol. 24 , no. 5, pp. 377-382. http://dx.doi.org/10.1590/S010286502009000500007. PMid:19851690.

CHEN, Y., ZHOU, C., GE, Z., LIU, Y., LIU, Y., FENG, W., LI, S., CHEN, G. and WEI, T., 2013. Composition and potential anticancer activities of essential oils obtained from myrrh and frankincense. Oncology Letters, vol. 6, no. 4, pp. 1140-1146. http://dx.doi.org/10.3892/ol.2013.1520. PMid:24137478. 
ESTEVAM, E.B.B., DEUS, I.P.B., SILVA, V.P., SILVA, E.A.J., ALVES, C.C.F., ALVES, J.M., CAZAL, C.M., MAGALHÃES, L.G., PAGOTTI, M.C., ESPERANDIM, V.R., SOUZA, A.F. and MIRANDA, M.L.D., 2017. In vitro antiparasitic activity and chemical composition of the essential oil from Protium ovatum leaves (Burceraceae). Anais da Academia Brasileira de Ciências, vol. 89, no. 4, pp. 3005-3013. http://dx.doi.org/10.1590/00013765201720170310 . PMid:29044326.

ESTEVAM, E.B.B., ALVES, C.C.F., ESPERANDIM, V.R., CAZAL, C.M., SOUZA, A.F. and MIRANDA, M.L.D., 2018. Chemical composition, anti-Trypanosoma cruzi and cytotoxic activities of the essential oil from green fruits of Protium ovatum (Bruseraceae). Revista Brasileira de Fruticultura, vol. 40, no. 1, pp. e-794. http://dx.doi.org/10.1590/0100-29452018794.

FERRAZ, R.P.C., CARDOSO, G.M.B., SILVA, T.B., FONTES, J.E.N., PRATA, A.P.N., CARVALHO, A.A., MORAES, M.O., PESSOA, C., COSTA, E.V. and BEZERRA, D.P., 2013. Antitumour properties of the leaf essential oil of Xylopia frutescens Aubl. (Annonaceae). Food Chemistry, vol. 141, no. 1, pp. 196-200. http:// dx.doi.org/10.1016/j.foodchem.2013.02.114. PMid:23768347.

HUSSAIN, A.I., ANWAR, F., CHATHA, S.A.S., JABBAR, A., MAHBOOB, S. and NIGAM, P.S., 2010. Rosmarinus officinalis essential oil: antiproliferative, antioxidant and antibacterial activities. Brazilian Journal of Microbiology, vol. 41, no. 4, pp. 1070-1078. http://dx.doi.org/10.1590/S1517-83822010000400027. PMid:24031588.

LI, Y.L., YEUNG, C.M., CHIU, L.C.M., CEN, Y.Z. and OOI, V.E.C., 2009. Chemical composition and antiproliferative activity of essential oil from the leaves of a medicinal herb, Schefflera heptaphylla. Phytotherapy Research, vol. 23, no. 1, pp. 140-142. http://dx.doi.org/10.1002/ptr.2567. PMid:18814213.

MATOS, I.A., MACHADO, S.M.F., SOUZA, A.R., COSTA, E.V., NEPEL, A., BARISON, A. and ALVES, P.B., 2015. Constituents of essential oil and hydrolate of leaves of Campomanesia viatoris Landrum. Quimica Nova, vol. 38, no. 10, pp. 1289-1292.

NASCIMENTO, K.F., MOREIRA, F.M.F., ALENCAR SANTOS, J., KASSUYA, C.A.L., CRODA, J.H.R., CARDOSO, C.A.L., VIEIRA, M.D.C., GÓIS RUIZ, A.L.T., ANN FOGLIO, M., CARVALHO, J.E. and FORMAGIO, A.S.N., 2018. Antioxidant, anti-inflammatory, antiproliferative and antimycobacterial activities of the essential oil of Psidium guineense Sw. and spathulenol. Journal of Ethnopharmacology, vol. 210, pp. 351-358. http:// dx.doi.org/10.1016/j.jep.2017.08.030. PMid:28844678.

OLIVEIRA, J.D., ALVES, C.C.F., MIRANDA, M.L.D., MARTINS, C.H.G., SILVA, T.S., AMBROSIO, M.A.L.V., ALVES, J.M. and SILVA, J.P., 2016. Rendimento, composição química e atividades antimicrobiana e antioxidante do óleo essencial de folhas de Campomanesia adamantium submetidas a diferentes métodos de secagem. Revista Brasileira de Plantas Medicinais, vol. 18, no. 2, pp. 502-510. http://dx.doi.org/10.1590/1983-084X/15_206.
OLIVEIRA, J.D., ALVES, D.K.M., MIRANDA, M.L.D., ALVES, J.M., XAVIER, M.N., CAZAL, C.M. and ALVES, C.C.F., 2017. Chemical composition of essential oil extracted from leaves of Campomanesia adamantium subjected to different hydrodistillation times. Ciência Rural, vol. 47, no. 1, pp. e20151131. http://dx.doi. org/10.1590/0103-8478cr20151131.

OLIVEIRA, L.A.R., MACHADO, R.D. and RODRIGUES, A.J.L., 2014. Levantamento sobre o uso de plantas medicinais com a terapêutica anticâncer por pacientes da unidade oncológica de Anápolis. Revista Brasileira de Plantas Medicinais, vol. 16, no. 1, pp. 32-40. http://dx.doi.org/10.1590/S1516-05722014000100005.

RIBEIRO, P.H.S., SANTOS, M.L., CAMARA, C.A.G., BORN, F.S. and FAGG, C.W., 2016. Seasonal chemical compositions of the essential oils of two Eugenia species and their acaricidal properties. Quimica Nova, vol. 39, no. 1, pp. 38-43.

SALVADOR, M.J., CARVALHO, J.E., WISNIEWSKI-JR, A., KASSUYA, C.A.L., SANTOS, E.P., RIVA, D. and STEFANELLO, M.E.A., 2011. Chemical composition and cytotoxic activity of the essential oil from the leaves of Casearia lasiophylla. Revista Brasileira de Farmacognosia, vol. 21, no. 5, pp. 864-868. http:// dx.doi.org/10.1590/S0102-695X2011005000073.

SANTOS, M.R.A., LIMA, R.A., SILVA, A.G., LIMA, D.K.S., SALLET, L.A.P., TEIXEIRA, C.A.D. and FACUNDO, V.A., 2013. Composição química e atividade inseticida do óleo essencial de Schinus terebinthifolius Raddi (Anacardiaceae) sobre a brocado-café (Hypothenemus hampei) Ferrari. Revista Brasileira de Plantas Medicinais, vol. 15, no. 4, pp. 757-762. http://dx.doi. org/10.1590/S1516-05722013000500017.

VIDAL, C.S., OLIVEIRA-TINTINO, C.D.M., TINTINO, S.R., GALVAO, H.B.F., COSTA, J.G.M., COUTINHO, H.D.M. and MENEZES, I.R.A., 2016. Chemical composition, antibacterial and modulatory action of the essential oil of Croton rhamnifolioides leaves Pax and Hoffman. Bioscience Journal, vol. 32, no. 6, pp. 1632-1643. http://dx.doi.org/10.14393/BJ-v32n1a2016-33918.

XAVIER, M.N., ALVES, C.C.F., CAZAL, C.M. and SANTOS, N.H., 2016b. Chemical composition of the volatile oil of Cardiopetalum calophyllum collected in the Cerrado area. Ciência Rural, vol. 46, no. 5, pp. 937-942. http://dx.doi.org/10.1590/01038478 cr20150371.

XAVIER, M.N., ALVES, J.M., CARNEIRO, N.S., SOUCHIE, E.L., SILVA, E.A.J., MARTINS, C.H.G., AMBROSIO, M.A.L.V., EGEA, M.B., ALVES, C.C.F. and MIRANDA, M.L.D., 2016a. Composição química do óleo essencial de Cardiopetalum calophyllum Schltdl. (Annonaceae) e suas atividades antioxidante, antibacteriana e antifúngica. Revista Virtual de Química, vol. 8, no. 5 , pp. 1433-1448. 